\title{
Chromosome number in Cephalocoema vittata (Proscopiidae, Orthoptera)
}

\author{
Carmen Albizu de Santiago ${ }^{1}$
}

\section{INTRODUCTION}

Cephalocoema vittata belongs to the family Proscopiidae, related to the superfamily Acridoidea of the order Orthoptera, though its general form reminds one at first sight of a Phasmidae. Proscopiidae is exclusively located in South America.

The species here discussed was named by Brunner $(1)^{2}$ in 1913 , after having collected it in the sorroundings of Cuzco, Perú.

Even though Acridoidea has been subjected extensively to cytological studies, little work, that we know of, has been done on the Neo-Tropical Proscopiidae. Makino (2) reports that determination of chromosome number in Proscopiidae has been limited to the work of Piza (3), who has studied Cephalocoema zilkari Piza and Tetanorhyncus mendesi Piza.

\section{MATERIALS AND METHODS}

The specimens of Cephalocoema vittata studied were collected in the locality of Cuzco, Perú, at an approximate altitude of $4,000 \mathrm{~m}$., during a trip taken by Dr. Niilo Virkki in January, 1966. Several specimens of the sample studied can be found at the Museum of the National Academy of Science, Philadelphia.

The specimens were fixed in 1:3 aceto-alcohol, making a lengthwise abdominal incision so as to expose the testes to the fixative. The following day the specimens were placed in 70-percent ethanol, and so transported to our laboratory, where they were kept in that medium until study on them began about 10 months later.

On preparing the tissue for observation a few drops of Kahle-Smith fixative were introduced through the incision, and the testes were immediately removed and placed in lacto-propiono-orcein for coloration.

The structure of the testes facilitated the preparation of the slides, since

1 Research Assistant in Cytogenetics, Department of Plant Breeding, Agricultural Experiment Station, Mayagüez Campus, University of Puerto Rico, Río Piedras, P.R. The author wishes to acknowledge the valuable cooperation of Dr. Niilo Virkki, Cytogeneticist Department of Plant Breeding, Agricultural Experiment Station, Rio Piedras, P.R., under whose direction this project was developed. We wish to express our gratitude to Dr. Francisco Carrasco, from the Univeraidad Nacional de Cuzco, and Prof. Oscar Ochoa, from the same Institution, for their valuable cooperation in collecting and identifying the specimens studied.

Italic numbers in parentheses refer to Literature Cited, p. 355. 
they are composed of numerous follicles of small size, convenient for obtaining good squashes. Squashes were made by placing the tissue on an albuminized slide, adding a drop of 45-percent acetic acid, covering, heating, and exerting pressure with the thumb. The slides that were selected for further study on a preliminary scan were then stained, using Feulgen reagent.

Photographs were taken using a Leitz Ortholux microscope with oil immersion objective, a Makam camera, and Kodak Contrast Process Ortho Film. For both negatives and prints Kodak's D-11 developer was used.

\section{OBSERVATIONS}

On examining the individual follicles of which the testes are composed, there appeared ample evidence that the complete meiotic cycle occurs in each of these structures. There is no reason to believe that a longitudinal or transverse gradient exists in the testes as a whole, since upon taking tissue samples from different regions, a more or less similar picture of activity was seen.

An abundance of gonial cells was usually observed, and also the presence of spermatids and mature sperms. In many instances one could also observe premeiotic mitosis as it occurs in cysts. The most abundant meiotic phases encountered were P I through M I. The second meiotic division apparently is much faster, for very little evidence of it was found among the 20 specimens studied.

The M I plates and A I movement afforded a clear picture of karyotype. The haploid chromosome number is observed as $n=8+X$ (fig. 1,A). This is in agreement with the observations made by Piza (3) on Cephalocoema zilkari Piza and Tetanorhyncus mendesi Piza in which he gives the chromosome number as being $n=8+X$ in the heterogametic sex.

The division of the heterochromosome is reductional in A I, equational in A II.

A gradual decondensation of $X$ occurs as the cycle progresses, passing from a positive heteropycnotic state, as seen in prophase nuclei, to a negative heteropycnotic state, as observed in Anaphase I (fig. 1,B).

The average number of chiasma per nucleus has been estimated as seven. Thirty-one diplotene nuclei, comprised in a single cyst, were used in establishing a chiasma count, but the material was not too favorable, since regions of chromosome torsion were very frequent, giving rise to doubt as to whether they were or were not points of chiasma formation. The index of recombination would, if so, equal 15 . Localization of chiasmata can be observed in 4 to 5 bivalents of Metaphase I (fig. 1,A).

Upon observing the shapes of chromosomes as they appear in figure 1,B, one could possibly conclude that they are all metacentric. This appears to be 
the more evident in the bigger chromosomes. This metacentric look is attributable to separation of chromatids of acrocentric chromosomes, as is often observed in A I. Metaphase I suggests acrocentry in probably all of the autosomes (fig. 1,A), and this is confirmed by Anaphase II. The exact shape of $X$ is very difficult to establish, though it apparently is metacentric.

\section{DISCUSSION AND CONCLUSIONS}

The results we have obtained in observing karyotype agree with those of Piza. Conclusions have not been drawn with respect to our observations of chromosome shape in Cephalocoema vitlata in comparison with the two

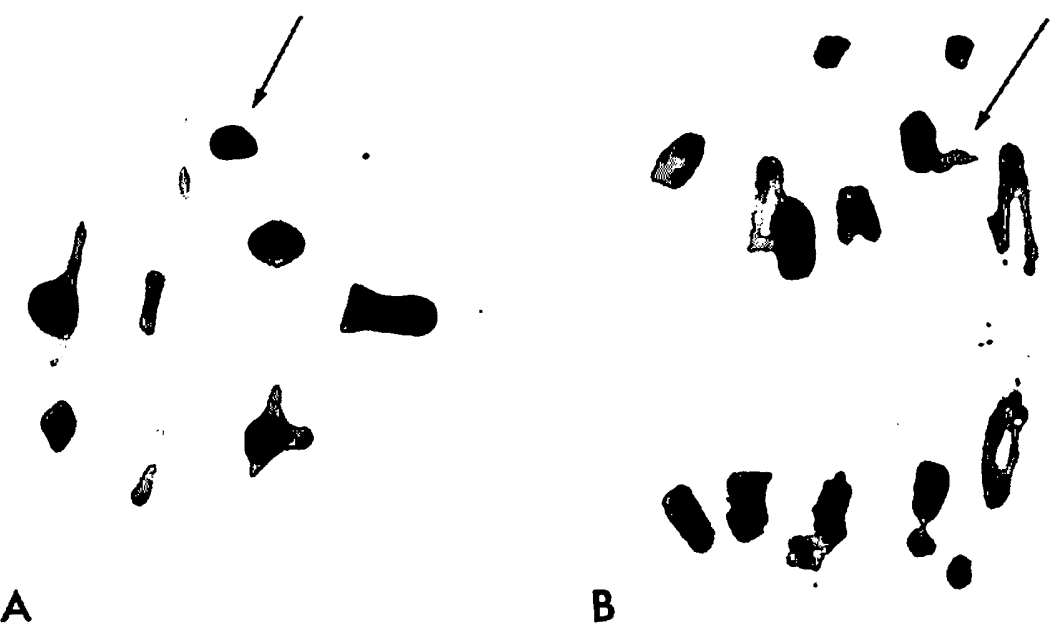

Fici. 1, A and B.-First meiotic division of Cephalococma villata. Arrow shows the univalent $\times$ chromosome: A. MI, $8^{11}+\times$. B.AI. Magnification $=2500 \times$.

species studied by Piza. From the illustrations provided in Piza's publication one can not affirm absolute similarities in terms of shape of $X$ and the autosomes. The author has not provided a drawing that includes all of the autosomes and the sex chromosome in any one of the phases he discusses. From that which can be observed in Piza's illustrations, the autosomes are apparently acrocentric, but we dare not conclude anything on $X$. Localization of chiasmata is apparent in two of the autosomes.

Proscopiidae is a family of the superfamily Acridoides. White (4) mentioned that Proscopiidae is an allied Scotropical family of the Eumasticidae, yet another Acridoidean family. The evidence obtained from our observations seems to fivor a close relationship between these two groups. McE lievan has recently grouped both families into the superfamily lumastacodea (5). 
The Eumasticidae $(6)$ have quite an extensive geographical range. They are found in both American Continents, and also in Cuba and Hispaniola of the Greater Antilles. Stal associated Proscopiidae and Eumasticidae basing his conclusions on morphological observations: "... they both agree in lacking auditory organs, or at least external evidence of auditory tympana".

Roberts (7) in 1940, tentatively reaffirmed the relationship between Eumasticidae and Proscopiidae. The Eumasticidae are apparently as old as the Acrididae; both forms have fossil evidence dating from the Oligocene.

Rehn (6) reported that cytological studies made by Helwig on Eumasticidae have provided a range of $2 n=17$ to $2 n=23$ as the chromosome numbers in the male. The chromosomes of this family exhibit acrocentry in all of its autosomes and metacentry in the sex chromosome. This evidently relates to our observations in Cephalocoema vittata.

From both these morphological and cytological facts, we could perhaps consider Proscopiidae as having branched off from the line of evolution of the Eumasticidae, now constituting a Neotropical family in its own right.

After concluding our work on Cephalocoema viltata we do not believe that it is the best example for utilization as illustrative material in a cytology course. The determination of chiasma frequency, among other things, is difficult. Other Orthopterans provide much better material that can be used to serve the purposes of a laboratory course in cytology.

\section{SUMMARY}

C'ephalocoema vittata belongs to the family Proscopiidae, an Acridoidean family of the Order Orthoptera. Its chromosome number has been established as $2 n=17$ in the male. The autosomes are apparently acrocentric, $X$ being metacentric. Considering both morphological and cytological evidence, Proscopiidae is closely related to the family Eumasticidae, an extensively distributed group, comparing in age with the Acrididae. We believe that it would be possible to consider Proscopiidae as a branch off of the Eumasticidae, now constituting a Ncotropical family in its own right.

\section{RESUMEN}

C'ephalocoema vittata pertenece a la familia Proscopiidae, acrídidos de la orden de los Ortópteros. Se ha establecido que el número de cromosomas en el macho es $2 n=17$. Los autosomas son aparentemente acrocéntricos y el $X$ metacéntrico. Al considerarse tanto la evidenica morfológica como la citológica, se establece la estrecha relación de la familia Proscopiidae con la Eumasticidae, grupo de extensa distribución cuya edad compara con la de los acrídidos. Creemos que la familia Proscopiidae se puede considerar como una rama de la Eumasticidae, la cual constituye hoy una familia Neo tropical por derecho propio. 


\section{LITERATURE CITED}

1. Brunner, Lawrence, Results of the Yale Peruvian expedition of 1911, Proc. U.S. Natl. Mus. 44: 177-87, 1913.

2. Makino, Sajiro, A Review of the Chromosome Numbers in Animals, p. 210, Hokuryukan, Tokyo, Japan, 1956.

3. Piza, S. de T., Comportamento do Heterocromossomio en alguns Ortópteros do Brasil, Luiz de Queiroz V., 1945.

4. White, M. J. D., Animal Cytology and Evolution, 2nd ed. Cambridge Univ. Press, England, 1954.

5. MeE Kevan, D. K., Chairman, Department of Entomology, MacDonald College of McGill Univ., Quebec, Canada, 1966. (By personal communication).

6. Rehn, J. A. G., The Acridoid family Eumasticidae, Proc. Natl. Acad. Sci. Philadelphia, Pa., 100: 77-139, 1948.

7. Roberts, H. R., Comparative Study of the Sub-fa. Acrididae primarily on the basis of their phallic structures, Proc. Natl. Acad. Sci. Philadelphia, Pa., 93: 201, 1941. 